\title{
A Fourth Amendment Approach to Compulsory Physical Examinations of Sex Offense Victims
}

\author{
Troy Andrew Eid $\dagger$
}

Alleged victims of sex crimes often consent to be physically examined by the prosecution's medical experts. Prosecutors have a constitutional duty to disclose their physicians' findings to the defense if they contain exculpatory evidence. ${ }^{1}$ But does due process entitle defendants' experts to probe the victim's body for evidence-even if the complainant objects? Defendants increasingly say yes. Some have asserted a due process right to have their own experts inspect the complainant's vagina or rectum for signs of sexual penetration. ${ }^{2}$ Others have argued that the trial court should use its inherent power to order such examinations-by defense or independent physicians-and to sanction complainants who refuse to comply. ${ }^{3}$

The Supreme Court has not considered whether the Due Process Clauses of the Fifth ${ }^{4}$ and Fourteenth ${ }^{5}$ Amendments extend to compulsory physical examinations of complainants. ${ }^{6}$ If the defendant's constitutional right does not reach that far, does the trial court nonetheless have the inherent power to order such an exam? Or do court-mandated vaginal and rectal examinations violate the complainant's right to be free from unreasonable searches under the Fourth Amendment? ${ }^{7}$

After a brief introduction to the controversy over compulsory physical examinations, Section II of this Comment discusses the

$\dagger$ A.B. 1986, Stanford University; J.D. Candidate 1991, The University of Chicago.

${ }^{1}$ See Brady v Maryland, 373 US 83, 87 (1963) and Section II.

* See Section III.

3 See Section IV.

- "No person shall ... be deprived of life, liberty, or property, without due process of law." US Const, Amend V.

- "No State shall ... deprive any person of life, liberty, or property, without due process of law." US Const, Amend XIV, $\S 1$. This Comment will refer to the Due Process Clauses of the Fifth and Fourteenth Amendments as the "Due Process Clause."

- Petition for certiorari was denied recently in Turner v Commonwealth, 767 SW2d 557 (Ky 1988), cert denied, 110 S Ct 260 (1989).

7 "The right of the people to be secure in their persons . . . against unreasonable searches and seizures, shall not be violated. ..." US Const, Amend IV. 
Supreme Court's due process analysis and concludes that it does not entitle defendants to compulsory examinations of complainants. Section III reviews the state court decisions that permit such exams, showing that while these decisions sometimes use the term "due process," their holdings consistently avoid the Due Process Clause and the Supreme Court's interpretation of it.

Section IV explores another possible basis for compulsory physical examinations, the courts' inherent authority to conduct criminal discovery. The section concludes, however, that this authority is limited by complainants' Fourth Amendment rights, and Section V shows that the Fourth Amendment protects sex offense victims from intrusive physical exams.

\section{The Controversy Over Compulsory Physical Examinations}

Physical examinations of complainants play a prominent role in many sex offense prosecutions. Ideally, the prosecution's physician inspects the complainant immediately after the alleged sexual contact to test for residual semen and other transitory evidence. ${ }^{8}$ An immediate examination can also increase the accuracy of the medical conclusions. ${ }^{9}$ In practice, however, the physician often cannot examine the complainant until several months after the most recent incident of alleged sexual penetration. Yet even under these circumstances, a physical examination is sometimes probative. Injuries to the hymenal ring of young girls, for instance, can produce scar tissue that lasts for years. The physical characteristics and location of the scarring may lead experts to attribute the injury specifically to male sexual penetration. ${ }^{10}$

Though no state requires that the prosecution present medical evidence of physical penetration to obtain a sex offense conviction, ${ }^{11}$ the prosecution's medical findings can be powerful tools of persuasion-especially if the only physician to examine the child

\footnotetext{
B Depending on the nature of the assault, a physical examination may include: an examination of the alleged victim's body for evidence of force or trauma; a thorough pelvic examination; taking pap smears from the vagina, anus, or mouth; and combing for foreign pubic hair. See People v Scott, 145 Cal Rptr 876, 578 P2d 123, 131 (1978) (Clark dissenting).

- The California Supreme Court has suggested a rule of thumb: "The more remote the incidents relied upon, the less probable it is that probative evidence will be discovered." Id at 128.

10 See Turner $v$ Commonwealth, 767 SW2d 557, 559 (Ky 1988), cert denied, $110 \mathrm{~S}$ Ct 260 (1989), where the examining physician testified that penile penetration caused the fouryear-old complainant's hymenal scars. Evidence of penetration can also be important in sodomy cases. Medical experts may attribute rectal scar tissue specifically to penile or digital penetration. See generally People v Nokes, 183 Cal App 3d 468, 228 Cal Rptr 119 (1986).

${ }^{11}$ See, for example, State v Ramos, 553 A2d 1059, 1062-63 (RI 1989).
} 
personally testifies at trial that the complainant's vagina or rectum has been sexually penetrated. Prosecutors also use this evidence to impeach defense experts and to corroborate the sometimes rambling and contradictory testimony of child witnesses. ${ }^{12}$ Still, the examining physician's opinion is hardly the last word. Physical evidence of penetration loses much of its probative value as the complainant's age increases; older children and teenagers are more likely to engage in voluntary sexual contact before and after the alleged offense. Nor is evidence of penetration tantamount to conviction when younger children are the alleged victims. Someone other than the defendant-even the children themselves-may have caused the scars. ${ }^{13}$ Consequently, prosecution and defense experts often derive different medical conclusions from a single physical examination.

Because few complainants consent to be examined physically by defendants' experts, accused sex offenders ordinarily wage a "secondhand defense." This means obtaining the examining physicians' medical reports as provided by federal ${ }^{14}$ or state $^{15}$ discovery rules, or by the Brady doctrine, which requires the prosecution to disclose any evidence in its possession that is exculpatory to the defendant. ${ }^{16}$ The defense is then free to cross-examine the prosecution's physicians at trial and to present expert testimony challenging their conclusions. This discovery is not as helpful to the de-

12 Turner, 767 SW2d at 558-59.

1s As the Kentucky Supreme Court noted, because "[s]mall girls sometimes masturbate or insert foreign objects into their vaginas which rupture the hymenal ring," it is a matter of expert opinion whether penile penetration caused the injury. Id at 559 .

${ }^{14}$ FRCrP 16 requires the prosecution to disclose to the defense various medical and scientific reports, including those pertaining to physical examinations. Section (a)(1)(D) provides:

Reports of Examinations and Tests. Upon request of a defendant the government shall permit the defendant to inspect and copy or photograph any results or reports of physical or mental examinations, and of scientific tests or experiments, or copies thereof, which are within the possession, custody, or control of the government, the existence of which is known, or by the exercise of due diligence may become known, to the attorney for the government, and which are material to the preparation of the defense or are intended for use by the government as evidence in chief at the trial.

${ }^{25}$ Approximately forty states have rules governing defense discovery. Wayne R. LaFave and Jerold H. Israel, 2 Criminal Procedure \$ 19.3 at 483 (West, 1984) ("Treatise"). Some states follow the federal standard. Others require that the prosecution disclose medical reports if the prosecution intends to use them at trial. But most state rules simply encompass all such reports "made in connection with the particular case." Wayne R. LaFave and Jerold H. Israel, Criminal Procedure 732 (West, 1985). Nearly all jurisdictions authorize discovery by the defense of reports and results of medical and physical examinations. LaFave and Israel, Treatise at 525.

16 Brady v Maryland, 373 US 83 (1963). See Section II. 
fendant as it might be. It is understandable that juries could be inclined to give greater credence to the examining physician than to an equally competent medical expert who has not personally inspected the complainant. ${ }^{17}$ Of course, if the trial court is concerned that the prosecution's medical findings are misleading or inaccurate, it can always exclude the evidence. But assuming that the prosecution's physician is highly credible to the jury, does it violate due process to prevent the defendant's experts from probing inside the complainant's vagina or rectum for evidence?

In answering no, some prosecutors have echoed the Supreme Court's admonition that " $[t]$ here is no general constitutional right to discovery in a criminal case." 18 They fear that compulsory physical examinations of complainants will make it more difficult to detect and deter sex crimes, in which the victim is often the sole witness. Prosecutors also raise the specter of the courts' practice in the 1940 s and '50s of routinely subjecting adult rape victims to psychiatric examinations, ${ }^{19}$ and warn that today's defendants could similarly intimidate victims of child molestation.

\section{Due Process and Discovery: The Supreme Court Cases}

Criminal discovery did not exist at the time of the Constitution's framing..$^{20}$ It was not until 1963 that the Supreme Court first interpreted the Due Process Clause to require the prosecution to disclose exculpatory evidence in its possession to the defendant. ${ }^{21}$

17 See State v Drab, 546 S2d 54, 56 (Fla Dist Ct App 1989), review denied, 553 S2d 1164 (Fla 1989) (rejecting this contention as a justification for compulsory physical exam).

18 Weatherford $v$ Bursey, 429 US 545, 559 (1977).

19 Dean Wigmore led the charge in favor of mandatory psychiatric examinations, proposing in his 1940 treatise on evidence that "[n]o judge should ever let a sex-offence [sic] charge go to the jury unless the female complainant's social history and mental makeup have been examined and testified to by a qualified physician." John Henry Wigmore, 3 Evidence $\$ 924$ (a) at 460 (Little, Brown, 3d ed 1940). See Section IV.

${ }_{20}$ As the Florida Supreme Court observed, "the common law does not authorize a court to require the physical examination of a witness, because discovery in criminal cases was unknown to the common law." State v Smith, 260 S2d 489, 491 (Fla 1972).

${ }^{21}$ Brady $v$ Maryland, 373 US 83, 87 (1963). The Court has generally declined to expand criminal discovery further, despite ample opportunities to do so. The proper scope of criminal discovery was hotly debated a generation ago, but has now been largely resolved by legislation or court rules. LaFave and Israel, 2 Treatise at 474 (cited in note 15). Proponents of liberal discovery stress the need to protect innocent defendants and to avoid surprise at trial. See William J. Brennan, Jr., The Criminal Prosecution: Sporting Event or Quest for Truth?, 1963 Wash U L Q 279; and Roger J. Traynor, Ground Lost and Found in Criminal Discovery, 39 NYU L Rev 228 (1964).

Opponents of liberal discovery are concerned with reciprocity. They note that the defendant's privilege against self-incrimination limits the legislature's ability to provide for extensive prosecution discovery from the defense. LaFave and Israel, Treatise at 476 . See 
Defendants have frequently asserted a due process right to have their experts inspect all prosecutorial files. Instead, the Court has required disclosure only of evidence that a prosecutor exercising due diligence would determine to be exculpatory. ${ }^{22}$ This duty extends only to evidence in the prosecution's possession. ${ }^{23}$

The Court has essentially viewed the appropriate scope of defense discovery as a matter of state legislative or judicial policy, within certain constitutional limits. ${ }^{24}$ The best known decision is Brady $v$ Maryland, which required the prosecution to disclose exculpatory evidence to the defense before trial if the defendant demands it. Defendant Brady, who faced a first-degree murder charge, demanded that the prosecution reveal all extrajudicial statements made by his accomplice concerning the crime. After the trial court convicted Brady and sentenced him to death, he learned that the prosecution had withheld a key statement in which the accomplice confessed that he, and not Brady, had done the killing. ${ }^{25}$ The Supreme Court held that withholding exculpatory evidence violates due process "where the evidence is material either to guilt or punishment, irrespective of the good faith or bad faith of the prosecution." ${ }^{26}$

The Court broadened the Brady doctrine in United States $v$ Agurs, which established that the prosecution has an affirmative duty to disclose exculpatory information in its possession even if the defendant has not specifically demanded it. Yet the duty to disclose is a limited one: "If everything that might influence a jury must be disclosed," the Court warned, "the only way a prosecutor could discharge his constitutional duty would be to allow complete discovery of his files as a matter of routine practice."27 More significantly, Agurs made the prosecution responsible for determining what evidence is exculpatory and therefore must be disclosed to

also Judge Learned Hand's famous articulation of this view in United States $v$ Garsson, 291 F Supp 646, 649 (S D NY 1923) ("Under our criminal procedure the accused has every advantage."). Finally, other commentators fear that expansive discovery will permit defense counsel to intimidate witnesses and facilitate perjury by enabling defendants to fabricate a defense after the fact, particularly since the prosecution cannot depose the defendant. LaFave and Israel, Treatise at 476-81.

22 The constitutional obligation to disclose depends not on the prosecution's good or bad faith, but on the materiality of the evidence: "If evidence highly probative of innocence is in his file, [the prosecutor] should be presumed to recognize its significance even if he has actually overlooked it." United States v Agurs, 427 US 97, 110 (1976).

${ }^{23}$ Id at 106-07, 111.

24 LaFave and Israel, Treatise at 481 (cited in note 15).

25373 US 83, 87 (1963).

${ }^{26}$ Id at 87.

27427 US 97, 108-09 (1976) (footnote omitted). 
the defendant. The Court might have given defense experts the right to scour the prosecution's files for material evidence. Instead, the Court determined that "[w]hether or not procedural rules authorizing such broad discovery might be desirable, the Constitution surely does not demand that much."28

The Court applied the doctrine of limited criminal discovery to a child molestation case for the first time in Pennsylvania $v$ Ritchie. Defendant Ritchie was convicted of raping his thirteenyear-old daughter. He subpoenaed the child protective services' files pertaining to her, but the agency refused to comply on the grounds that its records were privileged by statute and could be disclosed only to a "court of competent jurisdiction pursuant to a court order."29 The defendant then sought to have his experts inspect the files, but the trial judge refused. A divided Supreme Court held that Ritchie might have been denied a fair trial and remanded the case so that the trial court-not defense counsel-could conduct the inspection. ${ }^{30}$

At first glance, Ritchie appears to strike a blow at prosecutorial discretion by compelling an in camera inspection of the agency's files. But this conclusion is unwarranted. In Ritchie, the prosecution lacked access to the agency's files and was unaware of their contents; ${ }^{31}$ the Pennsylvania statute barred disclosure to all but the court. ${ }^{32}$ Ritchie, then, did not address the scope of prosecutorial disclosure since prosecutors never possessed the evidence sought by the defense. What Ritchie did do was reiterate that due process does not entitle defendants to inspect government files. As Justice Powell wrote for the Court:

${ }^{28}$ Id at 109 . Relying on the prosecution to disclose material evidence could admittedly lead to abuses. For instance, the examining physician and the prosecutor might conspire to withhold medical evidence from the defendant. See Turner $v$ Ward, 321 F2d 918 (10th Cir 1963) (reversible error where prosecutor instructed examining physician to testify in deliberately vague terms about medical findings of complainant's physical condition so that government could convict defendant of rape instead of less serious offense of sodomy). Nonetheless, the Court has insisted that it is the prosecution that decides which information must be disclosed, even though allowing complete discovery "may be helpful to a defendant in ferreting out information." Pennsylvania v Ritchie, 480 US 39, 59 (1987).

${ }^{29} 480$ US at $43-44$. The statute provided that "reports made pursuant to this act including but not limited to report summaries of child abuse . . . and written reports . . as well as any other information obtained, reports written or photographs or x-rays taken concerning alleged instances of child abuse in the possession of the ... agency ... shall be confidential. ..." Pa Cons Stat Ann § 2215(a) (Purdon Supp 1989).

so 480 US at 58.

31 Id at $44 \mathrm{n} 4$.

32 Id at $43-44$. 
To allow full disclosure to defense counsel in this type of case would sacrifice unnecessarily the Commonwealth's compelling interest in protecting its child abuse information. If the [agency] records were made available to defendants, even through counsel, it could have a seriously adverse effect on [the state's] efforts to uncover and treat abuse. ${ }^{3 s}$

The Court noted further that child abuse is one of the most difficult crimes to detect and prosecute because the victim is often the sole witness. "The Commonwealth's purpose would be frustrated," the Court concluded, "if this confidential material had to be disclosed upon demand to a defendant charged with criminal child abuse."\$4

In sum, the Court's decisions reveal that due process does not entitle defendants to obtain compulsory physical examinations of their alleged victims. Although the Court has ordered the prosecution to disclose exculpatory evidence in its possession, such as the written confession in Brady, it has consistently barred the defense from inspecting prosecutorial evidence firsthand with an advocate's eye toward what is and is not material. By this principle, the prosecution would have a duty to disclose medical reports pertaining to a physical examination of the complainant if they contain exculpatory evidence. But the prosecution cannot disclose what it does not have. Because the prosecution does not possess the complainant's vagina or rectum, it cannot "disclose" them to the defendant's experts via a compulsory physical examination..$^{35}$

33 Id at 60 .

st Id at 61 .

ss A complainant is arguably in the prosecution's "possession" in the sense that the prosecution may (through the court) subpoena witnesses and compel them to testify under threat of contempt. This type of possession is hardly absolute, however. The contempt power-coercive civil confinement or a separate criminal prosecution against a witness who willfully defies the court-necessarily ends where the complainant's Fourth Amendment rights begin. And even the grand jury is "without power to invade a legitimate privacy interest protected by the Fourth Amendment." United States $v$ Calandra, 414 US 343, 346 (1974). Moreover, since the defendant lacks a due process right to obtain a physical examination if the complainant refuses, it would make no difference if the court appointed an independent expert to inspect the complainant's vagina or rectum instead of the defendant's expert of choice. In either case, the state court's ability to expand criminal discovery beyond what the Due Process Clause requires must cease when it collides with the alleged victim's constitutionally protected dignity interests. See Section V. 


\section{State Courts That Order Physical Examinations in the Name of "Due Process"}

A number of state courts have held that due process entitles accused sex offenders to compulsory physical examinations of complainants. These courts are divided, however, as to the circumstances that trigger this entitlement. Still, the decisions do share a striking feature: they avoid mentioning the text of the Constitution and the Supreme Court's decisions interpreting it. This is no minor oversight. Given the Supreme Court's limited recognition of criminal discovery rights under the Due Process Clause, these state courts are plainly not engaged in proper federal constitutional decisionmaking, even though they sometimes use the term "due process" to justify outcomes in the cases before them. ${ }^{36}$

This section reviews, in turn, the various "due process" approaches that state courts have employed to assess a defendant's asserted right to compel a physical examination of the complainant. First is Kentucky's "material assistance" inquiry, which requires an examination when the evidence sought is likely to help the defendant prepare for trial. Second are two types of "compelling need" inquiries-an ad hoc balancing approach and a factorbased balancing approach - that loosely balance the defendant's interest in the evidence against the burden the examination would impose on the complainant. Third, the section considers the "exculpatory evidence" approach, which allows the defendant a physical examination only if the evidence likely to be obtained could absolutely bar his conviction. Fourth, the section discusses the "medical deficiency" standard, which permits an examination only if the prosecution's exam failed to conform to proper medical procedures. The section concludes by reviewing the state court cases that do ground their analysis in the Due Process Clause. These de-

\footnotetext{
${ }^{38}$ Of course, these courts could be basing their decisions on their state constitutions' analogues to the Due Process Clause. Beginning with Professor Donald Wilkes's influential article, The New Federalism in Criminal Procedure: State Court Evasion of the Burger Court, $62 \mathrm{Ky} \mathrm{L} \mathrm{J} 421$ (1974), commentators have frequently discussed the willingness of some state courts to preserve and expand the liberal discovery doctrines of the Warren Court. These courts have provided the accused greater protection by interpreting state constitutional provisions more expansively than the Burger and Rehnquist courts construed identical or parallel provisions of the federal Bill of Rights. See Yale Kamisar, Wayne R. LaFave, and Jerold H. Israel, Modern Criminal Procedure 63-68 (West, 6th ed 1986). But even assuming this is the case here, the Supreme Court's interpretation of the Fourth Amendment's guarantee against unreasonable searches should restrict a defendant's ability to obtain a compulsory physical examination of the complainant in a sex offense prosecution. See Section V.
} 
cisions have correctly rejected defense demands for compulsory physical examinations.

\section{A. The Turner Material Assistance Approach}

In Turner $v$ Commonwealth, the Kentucky Supreme Court held that the defendant was entitled "as a matter of due process and fairness" to have his own expert physically examine the complainant because the examination could lead to evidence "of material assistance to [him] in his cross-examination" of the prosecution's physician. ${ }^{37}$ The defendant in Turner had been convicted of first-degree rape and first-degree sexual abuse of his four-year-old daughter. The Kentucky Supreme Court acknowledged that his daughter's testimony, regardless of the medical evidence, was sufficient to permit a jury to find the defendant guilty. Nonetheless, the court reversed the defendant's conviction on the grounds that denying his request for a second physical examination of the complainant violated due process. "In this case," the Turner court said, "the alleged victim was only four years old. The physical examination of the child by an independent expert might have permitted the appellant to offer evidence to contradict that offered by the Commonwealth as to whether there were, in fact, any injuries to the hymenal ring." Had an independent expert found the same injury, the defendant might have been able "to contradict testimony for the Commonwealth that the location of the injuries indicated the probability of sexual penetration. In any event, the examination of the alleged victim by an independent expert and consultation with that expert as to the results of the examination would have been of material assistance to the appellant in his cross-examination" of the prosecution's physician. ${ }^{38}$

\section{B. The Compelling Need Approaches}

Some state courts that have allowed defendants to obtain a physical examination of the complainant require that there be a "compelling need" for the evidence likely to be found. Yet jurisdictions disagree as to what this phrase means. The decisions suggest two distinct approaches to determining compelling need: what this Comment will call an "ad hoc" balancing approach and a "factor specific" balancing approach.

s7 767 SW2d 557, 559 (Ky 1988), cert denied, 110 S Ct 260 (1989).

ss Id at 558-59. 
1. The ad hoc balancing approach.

The Illinois Supreme Court applied the ad hoc balancing approach in People $v$ Glover. Although Glover did not involve a request for a gynecological examination, the issues raised by the case are similar. The defendant in Glover appealed his conviction for deviate sexual assault against an adult woman and challenged the quality of her eyesight at the time of the incident. Specifically, he argued that the trial judge had deprived him of due process by refusing to order the complainant to submit to an ophthalmological examination, claiming that "it was dark at the time of the assault and the examination was necessary to determine her ability to see and identify the defendant." 39 The Illinois Supreme Court rejected this theory, explaining that, in weighing the competing considerations, there was no compelling reason for ordering an examination. The court did not elaborate as to what these considerations were, beyond identifying the defendant's request and its relative insignificance given the other evidence against him.

Similarly, in State $v$ Garrett the Minnesota Court of Appeals reversed a trial court order mandating a physical examination of the rape complainant, the defendant's fifteen-year-old daughter. The complainant's attorney had informed the judge that "'ff]rankly, if the Court orders [the examination], she would go ahead with it," " but the court held that the defense had failed to demonstrate the requisite compelling need. The court was unconvinced that a second examination-which the defendant hoped would reveal that the complainant had never had sexual intercourse, and therefore that he could not have raped her-_"would reveal anything probative for [the defendant]." Instead, it "would constitute an unnecessary annoyance and embarrassment to the complainant." Without further explanation, the Garrett court recognized that trial judges have "some discretion" in ordering physical examinations but warned that "[o]nly a rare case would justify such an order based upon a showing of compelling need."40 Unlike Glover, which balanced the defendant's request for new evidence against the probability that it might affect the outcome of the case, Garrett weighed the defendant's need for the evidence in view of the harm a court-ordered physical examination would impose on the complainant.

s9 $49 \mathrm{Ill} 2 \mathrm{~d} 78,273$ NE2d 367,369 (1971).

${ }^{40} 384$ NW2d 617, 619 (Minn App 1986). The court stressed that "[a]t trial, respondent will be able to cross-examine both the complainant and the doctor who performed her physical examination." 
Glover and Garrett both announce a compelling need standard but give trial courts virtually no guidance in determining when the defendant may obtain a compulsory physical examination of the complainant. Consequently, these ad hoc balancing "tests" are little more than assertions of highly fact-based conclusions.

\section{The factor-based balancing approach.}

Rhode Island is the only jurisdiction to adopt a second approach to determining compelling need, a factor-based balancing test. The test lists several specific considerations the trial judge must weigh in determining whether the defendant may obtain a compulsory physical examination of the complainant. In State $v$ Ramos, a Rhode Island jury convicted the defendant of repeatedly raping his twelve-year-old daughter at knifepoint. At trial, the state called as a witness the gynecologist who had physically examined the complainant a few months after the last alleged attack. She testified that she was "fairly certain" that the complainant's vagina had been penetrated. The defendant then moved to compel the complainant to submit to an independent physical examination to show "she was still a virgin and that the alleged sexual assaults never occurred." 1

The Rhode Island Supreme Court observed that it had "never considered whether a trial justice may compel a complaining witness in a criminal trial to undergo such a physical examination." The Ramos court then proceeded to articulate the following balancing test:

[T] he trial justice should consider: (1) the complainant's age, (2) the remoteness in time of the alleged criminal incident to the proposed examination, (3) the degree of intrusiveness and humiliation associated with the procedure, (4) the potentially debilitating physical effects of such an examination, and (5) any other relevant considerations. ${ }^{42}$

In rejecting the defendant's request, the Ramos court did not indicate the relative weight trial courts should give each of these fac-

61553 A2d 1059, 1060-62 (RI 1989). The state's expert physician stated that although she found no obvious caruncle or torn edges of the hymen generally associated only with childbirth or very traumatic intercourse, the complainant's hymen was stretched, allowing for easy penetration into her vagina. Thus, comparing her examination of the complainant to vaginal examinations performed on other thirteen-year-old females, the physician concluded that she was "fairly certain" the complainant's vagina had been sexually penetrated.

12 Id at 1062. 
tors. Nor did it suggest what "other relevant considerations" might be.

\section{The Exculpatory Evidence Approach}

Rather than engaging in balancing to determine whether the defendant may have his own physician conduct a physical examination, a handful of jurisdictions have based their decision on whether the evidence sought would be exculpatory. These courts have inquired whether the evidence likely to be obtained by a compulsory physical examination could absolutely bar a conviction. If not, the court should refuse to order such an examination regardless of the circumstances involved.

Practically speaking, the exculpatory evidence approach should deny a compelled physical examination when (1) the substantive offense does not require proof of physical penetration; or (2) the offense requires a finding of sexual penetration but the factfinder is free to determine whether penetration actually occurred by weighing both medical and non-medical evidence. Even an examination favorable to the defendant could not absolutely assure exoneration in either case; the defendant might still be convicted even if the examination yields no signs of sexual penetration. ${ }^{43}$ Given that even a clear showing of no sexual penetration might not prove exculpatory, a standard resting an examination order on its "absolutely exculpatory" character should impose an insuperable burden on most defendants. ${ }^{44}$

The California Court of Appeal adopted the exculpatory evidence approach in People $v$ Nokes. The court denied the defendants' motion to compel a physical examination of the complainant because the evidence that might have been obtained would not have mandated a verdict for the defendants. The Nokes defendants were charged with committing 133 lewd and lascivious acts against seven children, including vaginal and anal penetration of their six-year-old daughter and anal penetration of their four-yearold son. ${ }^{45}$ At a preliminary hearing, the defendants moved for compulsory physical examinations of the daughter and son. ${ }^{46}$ The mag-

\footnotetext{
43 See text at note 11 .

14 In theory, a defendant might still satisfy the exculpatory evidence standard if the prosecution's medical findings are its sole evidence of sexual penetration.

45 183 Cal App 3d 468, 471-72, 228 Cal Rptr 119 (1986).

16 Id at 473-74. The son had not previously undergone any physical examination and was unwilling to do so. The defendants argued he should submit to an anal examination and that the daughter should submit to a vaginal and anal examination.
} 
istrate refused on the grounds that the proposed examinations could not exculpate the defendants: the evidence that might be obtained could not by itself establish that the children had not been molested. The magistrate added that the son's unwillingness to agree to the examination (he feared it would replicate the alleged abuse) rendered the proposed bodily intrusion impermissible. ${ }^{47}$ The trial court reversed the magistrate's order, but the California Court of Appeal reinstated it. ${ }^{48}$ In doing so, the appellate court noted that "while signs of scarring from old tears would be positive evidence that the child had been molested, the absence of such evidence, i.e., normal results of an examination, would not establish that the child had not been molested." 49

The North Carolina Court of Appeals relied partially on the exculpatory evidence approach in State $v$ Hewett. The defendant, who was convicted of repeatedly raping his two young daughters, had obtained copies of the examining physician's report, which concluded that the size of the vaginal openings of both girls was "consistent with," but not "diagnostic of," the kind of sexual abuse the children had described to him. ${ }^{50}$ The defendant moved to have his own expert physically examine the daughters, but the trial judge refused out of concern for the children's well-being and because the evidence sought could not exonerate him. The North Carolina Court of Appeals affirmed the trial court. It noted that the evidence sought from a second examination could not exculpate the defendant because the last alleged incident of sexual abuse had taken place six months earlier, giving the girls' vaginal openings time to constrict to their normal size. ${ }^{51}$

17 Id at 474.

48 Id at 482 .

49 Id at 480 .

so 93 NC App 1, 376 SE2d 467, 470 (1989). The examining physician wrote that the hymenal ring of the first girl "f[ell] open to some $8 \mathrm{~m}$ [illimeters] and ha[d] a thickened internal edge." This made him believe the ring had "been injured and healed." Id. The vagina of the second girl "gape[d] to 7 or $8 \mathrm{~m}$ [illimeters and the] edge of the hymenal ring [was] somewhat thickened and g[ave] the impression of having been irritated and healed." Id. The physician testified that according to the consensus group of the American Medical Association, a vaginal opening of ten millimeters is "pretty much proof of penetration," while an opening of more than four millimeters "is very suggestive of penetration." Id at 471.

s1 Id at 471-72. See also Sluka v State, 717 P2d 394, 401 n 6 (Alaska App 1986) (failure to require a second medical examination for three-year-old assault victim was not error in absence of a showing as to how the examination would have been probative to defendants). 


\section{The Medical Deficiency Approach}

Hewett also noted the defense's failure to show that the prosecution's medical findings were deficient. ${ }^{52}$ At least one other court has suggested that the defendant must show that the physical examination was conducted improperly. In State $v$ Drab, the defendant, who was charged with sexual battery of a child, moved for a second gynecological examination of the complainant, his eightyear-old adopted daughter. The Florida District Court of Appeal prohibited the exam because the defendant "takes issue not with the qualifications of the original examiner nor with the specifics of his physical observations, but rather with the conclusions drawn therefrom." The court observed that the defendant "has not alleged that there was anything improper or unprofessional about the voluntary physical examination of the complaining witness. $\mathrm{He}$ does not urge that the scientific observations that were made are in any way suspect. He faults only the conclusion that these findings lend support to the allegations of sexual abuse." "B4 Because the defendant already had access to the examining physician's medical report, the court held that the defendant's ability to raise a defense was not infringed.

In addition to proposing a requirement of medical deficiency, Drab is significant for expressly grounding its analysis in the defendant's right to due process. ${ }^{55}$ The other decisions discussed above-with the exception of the Kentucky Supreme Court in Turner $v$ Commonwealth ${ }^{58}$ - steered clear of the due process argument even when the defense had raised it. ${ }^{57}$ But like Turner, which never mentioned the Brady-Agurs line of cases, ${ }^{58}$ Drab ignored the Supreme Court's due process jurisprudence. Instead, Drab cited approvingly the decision of another branch of the Florida District Court of Appeal in a child molestation case, State $v$ Diamond:

There the court held that where compelling circumstances exist so that an accused may be deprived of his due process

52 376 SE2d at 472. The court explained that the defendant had not challenged the conclusions of the prosecution's physician as inconsistent with the physical findings.

ss 546 S2d 54 (Fla Dist Ct App 1989), review denied, 553 S2d 1164 (Fla 1989).

s4 Id at 56 .

s. Id at 55.

s8 767 SW2d at 559 .

s7 For example, in Glover, 273 NE2d at 369-70, the defendant alleged a due process violation but the Illinois Supreme Court framed its holding solely in terms of whether the trial court abused its discretion, thereby avoiding the constitutional issue entirely.

${ }^{58}$ See Section II. 
rights unless the complaining witnesses are compelled to undergo a physical examination, the state should be precluded from introducing as evidence at trial the results of a previous voluntary examination unless and until the complaining witnesses voluntarily submit to a physical examination by a qualified physician of the defendant's choice. ${ }^{59}$

Drab reasoned that the Diamond approach, "with the emphasis on the method of safeguarding a defendant's due process rights," avoided the difficult question of determining whether the trial court has inherent authority to compel physical examinations of complainants. ${ }^{60}$ Drab also stated that Diamond was consistent with the complainant's right of privacy, as guaranteed by the common law and the Florida Constitution. ${ }^{61}$ Diamond itself, however, did not mention the Supreme Court's due process decisions, although it referred both to the state and federal constitutions. ${ }^{62}$

\section{E. No Defense Right to Compel a Physical Examination}

In contrast to the decisions discussed above, which at least have purported to recognize that physical examinations might sometimes be compelled, several state courts have held that there is no constitutional basis for defense-demanded physical exams of alleged sex offense victims. Although the California Court of Appeal in People $v$ Nokes relied partly on the exculpatory evidence rationale, it also questioned whether accused sex offenders would ever have a right to compel a physical examination that intruded into the complainant's rectum or vagina. The Nokes defendants had demanded that the complainants, their two minor children, submit to physical examinations. In denying the defendants' request, the Court of Appeal concluded that the defendants erred by suggesting that their constitutional right to present an affirmative defense "somehow transform[ed] their right to seek discovery into an absolute right to discovery, of equal constitutional force." ${ }^{\prime 3}$

\footnotetext{
so Drab, 546 S2d at 55, citing State v Diamond, 553 S2d 1185, 1190 (Fla Dist Ct App 1988). Diamond upheld the trial court's decision to order the complainant, an eight-yearold girl, to submit to a gynecological examination at the insistence of the defendant, who was charged with raping her. The court held that denying the proposed examination would deprive the defendant of his right to due process because "the court's power to enforce constitutional rights stems from the constitution itself." Diamond, 553 S2d at 1190.

so Drab, 546 S2d at 55 .

61 Id at 55-56.

2 Diamond, 553 S2d at 1190.

es $183 \mathrm{Cal}$ App 3d at 479 (emphasis in original).
} 
Other jurisdictions have echoed this point. In State ex rel Wade $v$ Stephens, the Texas Court of Appeals held that the defendant could not compel a physical examination of his ten-yearold daughter, the alleged victim of aggravated sexual assault, because his "controversial discovery order is not supported by either the federal or state constitution." peals ruled in State $v$ Holmes, a child molestation case, that "there is no right of a defendant to compel the victim of sexual abuse, especially a child, to submit to a gynecological examination." court simply did not consider the defendant's motion to be of constitutional dimension: "We have previously indicated the rules of criminal procedure do not even sanction the deposition of a crime victim, absent extraordinary circumstances, partly because of the possible harassment to the victim." relied partially on the exculpatory evidence approach, the North Carolina Court of Appeals also implied that defendants have no due process right to compulsory physical examinations when it refused to order one unless the complainants or their guardians consented to it. ${ }^{67}$ Finally, the Florida Supreme Court denied a compulsory physical examination in State v Smith, a non-sex-offense case. The defendants in Smith convinced the trial judge that certain prosecution witnesses should be examined for visual acuity prior to trial..$^{68}$ The state's highest court quashed the order because neither the common law nor any state rule of criminal procedure "purport[ed] to authorize a trial court to grant a motion compelling witnesses to submit to a physical examination of any sort."

Because these decisions are consistent with the Court's due process jurisprudence, they avoid the errors made by the Kentucky Supreme Court in Turner and the Florida District Courts of Appeal in Drab and Diamond. To borrow a phrase from the Nokes opinion, the defendants in Turner and Drab were mistaken in suggesting that their due process right to present an affirmative defense "transforms their right to seek discovery into an absolute right to discovery, of equal constitutional force."'o Justice Wintersheimer of the Kentucky Supreme Court, dissenting in Turner, recognized the fallacy of the defendant's due process theory, con-

o. 724 SW2d 141, 143 (Tex Crim App 1987).

es 374 NW2d 457, 459 (Minn App 1985).

${ }^{86}$ Id (emphasis in original). See also Lanton v State, 456 S2d 873 (Ala Crim App 1984).

376 SE2d at 472.

es 260 S2d 489, 489-90 (Fla 1972).

"Id at 491.

7o Nokes, 183 Cal App 3d at 479 (emphasis added). 
cluding that Turner had "received all that he was entitled to" under state rules of criminal procedure and could demand no more. Wintersheimer explained:

[The defendant] received all results and reports of physical or mental examinations and of scientific tests or experiments made in connection with the prosecution. He had every opportunity to review the examination procedures and findings of the testifying prosecution physician. The defense is surely entitled to an opportunity for effective cross-examination but not cross-examination to every extent the defense might wish. A review of the record indicates a thorough and extensive cross-examination by defense counsel. There was nothing to prevent the defendant from having his own expert testify at trial in an attempt to impeach the prosecution witness. ${ }^{71}$

Justice Wintersheimer's dissent mirrors the U.S. Supreme Court's due process jurisprudence in the Brady-Agurs line of cases; it likely represents the approach the Court would have taken had it granted certiorari in the case. ${ }^{72}$

\section{Trial Courts' Inherent Power to Order Physical EXAMINATIONS}

Due process arguments aside, every state recognizes that trial courts have the inherent authority to control criminal discovery, including pretrial disclosure of certain medical reports. ${ }^{73}$ But the scope of this discretionary power is unclear. Unlike civil discovery, where the court may order medical examinations if the condition of a party is in controversy, ${ }^{74}$ there are no statutes-federal or

71 Turner, 767 SW2d at 562 (Wintersheimer dissenting) (citation omitted).

72 See note 6.

73 LaFave and Israel, Treatise at 482-83 (cited in note 15).

${ }^{34}$ Rule 35 of the Federal Rules of Civil Procedure applies to "physical and mental examinations of persons," and the Advisory Committee notes make clear that "reports of examining physicians are discoverable not only under Rule 35(b) but under other rules as well." FRCP 35(b)(3) Advisory Committee Note, in Federal Rules of Civil Procedure 302 (Foundation, 1988). Rule 35(a) provides: "When the mental or physical condition (including the blood group) of a party, or of a person in the custody or under the legal control of a party, is in controversy, the court ... may order the party submit to a physical or mental examination by a physician...." Under Rule $35(b)(1)$, the party causing the examination to be made must deliver to the person examined, or the party against whom the motion is made under 35(a), "a copy of a detailed written report of the examining physician setting out the physician's findings, including results of all tests made, diagnoses and conclusions, together with like reports of all earlier examinations of the same condition." The party causing the examination is entitled to obtain like reports by the other party on request-unless those reports pertain to a non-party over whom the court lacks jurisdiction. Finally, 35(b)(1) 
state- that expressly provide for court-ordered physical examinations of complainants in criminal proceedings. Many courts simply state that the defendant's request falls within the trial court's "sound discretion" to ensure a just disposition of the cause, thereby avoiding any further analysis. ${ }^{75}$ Still, a number of jurisdictions have offered some specific analogies to support their view of inherent authority. This section briefly reviews these analogies, then discusses the sanctions that trial courts use to compel physical examinations.

\section{A. The Trial Courts' Analogies}

1. Civil discovery.

Some state courts holding that it is within the "sound discretion" of the trial judge to order a physical examination of the complainant at the defendant's request have analogized to civil cases, where the judge may order such examinations if the medical condition of the parties is in controversy. ${ }^{76}$ The Kentucky Supreme Court hinted at this approach in Turner $v$ Commonwealth, but admitted that the analogy was problematic because the complainant in a criminal case is never a party or under the control of a party to the action. ${ }^{77}$ Whereas civil plaintiffs voluntarily put their physical condition at issue by filing an action, complainants in sex offense prosecutions do not.

\section{Court-ordered psychiatric exams.}

Some courts have derived authority to order physical examinations of complainants in sex offense prosecutions from precedent or state criminal procedural rules empowering them to order psychiatric examinations in such cases. Indeed, Dean Wigmore and several other academic commentators of his generation urged that all complainants in rape and child molestation prosecutions un-

lets the court sanction non-complying parties by withholding evidence: "[I]f a physician fails or refuses to make a report the court may exclude the physician's testimony if offered at trial."

Most states pattern their civil discovery provisions pertaining to medical examinations after the federal rules. Typical are the Florida Rules of Civil Procedure, which provide that either party may request the other party to submit to an examination by a "qualified expert" when the "condition that is the subject of the requested examination is in controversy and good cause has been shown." Fla RCP 1.360(a) (West, 1990).

75 See, for example, State $v$ Garrett, 384 NW2d 617, 619 (Minn App 1986), discussed in the text at note 40 .

78 See note 74.

$77^{\circ} 767$ SW2d at 559. 
dergo compulsory psychiatric examinations. ${ }^{78}$ These commentators feared that innocent defendants would otherwise be convicted, and warned that complainants might be afflicted with mental disorders such as pseudologia phantastica, a medical condition in which "[g]irls assert that they have been raped, sometimes recounting as true a story they have heard, falsely naming individuals or describing them." These views have since been almost universally discredited-and justly so. ${ }^{80}$ Nevertheless, some courts continue to claim broad inherent powers to compel psychiatric testimony of sex offense complainants. For instance, in Ballard $v$ Superior Court of San Diego County, the California Supreme Court rejected Wigmore's proposed compulsory psychiatric examinations, ${ }^{\mathbf{8 1}}$ but held that the trial judge possessed the inherent authority to order the complainant in a sex offense prosecution to undergo a psychiatric examination if the defendant presented a compelling reason for doing so. ${ }^{82}$

Other courts have extended this reasoning to physical examinations. For example, in People $v$ Visgar, the defendant was convicted of raping his minor daughter, and the court denied his request that she submit to a physical examination. The defendant argued on appeal that such an exam would reveal "whether the complainant's hymen was intact" and was therefore "highly relevant to the credibility of her allegation that defendant had intercourse with her." The Illinois Court of Appeals affirmed the conviction, but only because the defendant was charged with having "lewdly fondled or touched" the complainant-an offense as to which a physical examination would not be probative. ${ }^{83}$ In reaching this conclusion, the Visgar court specifically rejected the prosecution's argument that the trial court was powerless to order a physical examination: "the State provides no reason to distinguish be-

78 See note 19.

70 Ballard v Superior Court of San Diego County, 64 Cal 2d 159, 410 P2d 838, 846 n 6 (1966), quoting Roscoe N. Gray, 1 Gray's Attorneys' Textbook of Medicine 940 (M. Bender, $3 d$ ed 1949). "This concern," the Ballard court explained, "is stimulated by the possibility that a believable complaining witness, who suffers from an emotional condition inducing her belief that she has been subjected to a sexual offense, may charge some male with that offense. Thus, the testimony of a sympathy-arousing child may lead to the conviction of an unattractive defendant, subjecting him to a lengthy prison term." Ballard, 410 P2d at 846.

${ }^{\circ 0}$ "See text at notes 85-87.

a1 $410 \mathrm{P} 2 \mathrm{~d}$ at $848-49$.

s. Id at 849 .

ss $120 \mathrm{Ill}$ App 3d 584, 457 NE2d 1343 (1983). 
tween psychiatric and physical examinations of the complainant with regard to a trial court's jurisdiction to order one."

But Visgar is very much the exception to the rule. In the analogous area of psychiatric examinations, courts are now extremely reluctant to order sex offense complainants to submit to testing. The only state court to adopt Wigmore's approach overruled it four years later, ${ }^{85}$ and many state courts have since restricted trial courts' ability to order psychiatric examinations. ${ }^{86}$ Elsewhere, legislatures have stepped in: the California legislature rejected Ballard, and other states have taken similar measures to confine the trial court's discretionary authority to order psychiatric examinations. ${ }^{87}$

3. Rules authorizing discovery of tangible evidence.

At least one defendant has theorized that a physical examination request comes within state procedural rules authorizing the discovery of tangible evidence from the prosecution. In State $v$ Hewett, the North Carolina Court of Appeals rejected the defendant's comparison of the complainant's body to hypothetical white powder found on his person at the time of his arrest. "Powder," the court retorted, "does not have dignity." 88

84 457 NE2d at 1346.

8s Burton v State, 232 Ind 246, 111 NE2d 892 (1953) (requiring complainant to undergo psychiatric examination), overruled by Wedmore $v$ State, 237 Ind 212, 143 NE2d 649, 654 (1957). Moreover, scholarship on the issue of compulsory psychiatric examinations has dwindled in recent years. But see Steven W. Feldman, Sexual Offense Prosecutions: The Defendant's Right to Obtain a Mental Examination of the Complaining Witness, 24 Tenn Bar J 22 (1988).

${ }^{\text {so }}$ See State $v$ Drab, $546 \mathrm{~S} 2 \mathrm{~d}$ at 55 (Florida statute permits trial judges to order psychiatric examination of alleged victims of child molestation but not rape complainants); and State $v$ Hewett, 376 SE2d at 472 ("The law in this state is that a judge has no discretionary power to require an unwilling witness to submit to [a psychiatric] examination.") (emphasis in original).

87 Cal Penal Code $\$ 1112$ (West 1985) forbids trial courts from compelling psychiatric examinations of any witness, including complainants, for the purpose of assessing credibility. The California Court of Appeal interpreted $\S 1112$ as depriving trial judges of their inherent power to order psychiatric examinations. People v Armbruster, 163 Cal App 3d 660, 664, 210 Cal Rptr 11 (1985). "Due process," Armbruster concluded, "does not compel pretrial discovery in favor of a defendant." Id. For a similar view, see II Rev Stat ch 38, $\S 115-7.1$ (1987), providing that "no court may require or order a witness who is the victim of an alleged sex offense to submit to or undergo either a psychiatric or psychological examination."

${ }^{88} 376$ SE2d 467, 471 (NC App 1989). 
In sum, while these different analogies vary in persuasiveness, the trial court's inherent power to order discovery conceivably includes compulsory physical examinations of complainants in the absence of: (1) statutory provisions to the contrary; (2) countervailing common law doctrines; or (3) constitutional rights such as the complainant's Fourth Amendment guarantee to be free from unreasonable searches. ${ }^{89}$

B. The Trial Courts' Ability to Sanction Complainants Who Refuse to Undergo Physical Examinations

Even if trial courts had the authority to order physical examinations of complainants, how could they enforce it? One option is to sanction the prosecution. Courts have sometimes done so when complainants have refused to submit to physical examinations, both to avoid any perceived unfairness to the defense and to induce the complainant to acquiesce to the proposed exam.

The sanctions can take various forms. In State $v$ Drab, the Florida District Court of Appeal ordered that "the state should be precluded from introducing as evidence at trial the results of a previous voluntary examination unless and until the complaining witnesses voluntarily submit to a physical examination by a qualified physician of the defendant's choice."90 Under a second approach, discussed but not adopted by the Texas Court of Appeals in State ex rel Wade $v$ Stephens, the court would prevent the complainant from testifying until she consented to the proposed examination. ${ }^{91}$ A third approach, endorsed by the California Supreme Court in Ballard, permits the judge to comment on the complainant's refusal to submit to an examination..$^{22}$ Finally, one Florida trial court faced with an unwilling complainant in a sex offense case enjoined the prosecution until the complainant consented. However, this extreme measure did not survive on appeal..$^{93}$

With the exception of dismissing the prosecution, these sanctions all appear to fall within the trial court's sound discretion to provide a just and orderly disposition of the case, provided the court has discretionary power to compel physical examinations in the first place. Many courts will no doubt continue to claim this

- The Fourth Amendment argument is taken up in Section V.

90 Drab, $546 \mathrm{~S} 2 \mathrm{~d}$ at 55.

32 SW2d at 144-45.

92 410 P2d at 849. Note that Ballard addressed the issue of sanctions in the context of psychiatric examinations.

${ }^{93}$ State v Diamond, 553 S2d 1185, 1189 (Fla Dist Ct App 1988). 
power absent statutory barriers-unless and until complainants can establish that compulsory physical examinations violate their Fourth Amendment rights.

\section{Applying the Fourth Amendment to Compulsory Physical EXAMinations of Complainants}

The preceding sections have illustrated that the Supreme Court's limited recognition of a constitutional entitlement to criminal discovery does not support defendants' asserted right to have their own physicians, or those appointed by the court, examine complainants in sex offense cases. Of course, that the Supreme Court has failed to recognize this right does not necessarily mean that state courts may not order such examinations under their own authority. Nor, more importantly, does the unavailability of such a right under the federal Constitution mean that state courts may not provide it under their own constitutions' analogues to the Due Process Clause. ${ }^{94}$ This section, however, offers an affirmative argument against such state court extensions, showing that not only is a defense examination of the complainant not compelled by the Supreme Court's due process analysis, it is in fact prohibited by the Court's explication of the Fourth Amendment's guarantee against unreasonable searches.

A physical examination is "compulsory" if the complainant would not freely consent to it absent court-imposed sanctions. One might respond that court-ordered examinations are always voluntary in the sense that the complainant remains "free" to drop the charges. Yet this argument ultimately misses the mark. It is the prosecution-not the complainant-that brings charges against an accused sex offender in order to vindicate the interests of society. Although the victim's reluctance to become involved in a prosecution may affect the state's decision, it is not dispositive. ${ }^{95}$

This underscores the crucial distinction between a complainant and a party to a civil suit. Neither the civil plaintiff nor the complainant consented to the initial physical harm caused by the defendant. But by bringing a civil suit against the wrongdoer, the plaintiff consents to placing her physical integrity on the line in order to gain a personal compensatory benefit. Similarly, the civil

\footnotetext{
84 See note 36.

85 As the charging decision is made by the prosecutor, victims play no formal part in deciding whether to prosecute. See generally Sarah N. Welling, Victims in the Criminal Process: A Utilitarian Analysis of Victim Participation in Charging Decisions, 30 Ariz L Rev 85, 94, 105 (1988).
} 
defendant can settle the claim, thus avoiding the court's compelling him to undergo a physical examination. In commenting on Fourth Amendment interests in the civil context, Professor Tribe has argued that "the simple fairness of not letting a party both claim a fact and conceal the only evidence that could verify or disprove it [makes] it impossible to say that the party [is] being forced to yield a right." Reciprocity, Tribe suggests, helps explain the Court's decision to uphold the federal rule requiring civil parties to submit to medical examinations when they have put their physical condition at issue..$^{96}$

However, a complainant facing a compulsory physical examination cannot settle a claim like a civil defendant or drop the suit like a plaintiff, for it is the state that brings the charges. There is no reciprocity or consent in a criminal proceeding. The "benefit" of enforcing sex offense laws accrues to society and not to the victim. Forcing complainants to undergo intrusive examinations by defense experts does not result in a reciprocal benefit to complainants beyond the collective welfare. As Tribe warns, "[a] requirement of reciprocity serves to minimize the danger that a bodily invasion will be justified on the basis that the greater good of society is served thereby." Tribe applies his analysis only to civil discovery, but his reciprocity argument carries even greater force in the context of compulsory physical examinations. Requiring the alleged victims of sex crimes to submit to physically intrusive inspections for society's sake is impermissible precisely because it treats them "as a means to the ends of others."

\section{A. The Scope of Fourth Amendment Protection for Complainants}

Having established that defense examinations of complainants are in fact "compelled," the next question is whether complainants who face such examinations are entitled to the same degree of Fourth Amendment protection as defendants. The Court has not considered the issue directly, but there is strong indication that its Fourth Amendment decisions extend by implication to complainants. The Court said as much in Camara v Municipal Court: "It is surely anomalous to say that the individual and his private property are fully protected by the Fourth Amendment only when the

\footnotetext{
${ }^{96}$ Laurence H. Tribe, Constitutional Law 1334 (Foundation, 2d ed 1988).

${ }^{97}$ Id at 1334-35.
} 
individual is suspected of criminal behavior."98 Not surprisingly, lower courts have assumed that the Fourth Amendment protects defendants and complainants alike. For example, in Daryl $H . v$ Coler the Seventh Circuit applied the Fourth Amendment to physical examinations by government officials of alleged victims of child abuse. ${ }^{99}$ At the state level, the Georgia Supreme Court in State $v$ Haynie rejected a defense request to force the complainant to undergo surgery to remove a bullet: "The Fourth Amendment right of the victim to be secure against an unreasonable search must prevail over the right of the accused to obtain evidence for his defense." 100

To determine whether a search of an individual is reasonable under the Fourth Amendment, the Supreme Court has focused on the degree of physical intrusiveness. The most intrusive searches warrant a finding of compelling need, the most stringent standard of antecedent justification. In Winston $v$ Lee, the Court held that court-ordered surgery on an attempted robbery suspect to remove a bullet allegedly fired by his victim violated the defendant's Fourth Amendment rights. ${ }^{101}$ Writing for the Court, Justice Brennan held that even the bullet's potential probativeness as evidence could not justify such an extreme intrusion: "A compelled surgical intrusion into an individual's body for evidence ... implicates expectations of privacy and security of such magnitude that the intrusion may be 'unreasonable' even if likely to produce evidence of a crime."102 The proposed surgery in Winston infringed the defendant's interest in personal bodily integrity. ${ }^{103}$

The Winston Court contrasted the facts of that case to those of Schmerber $v$ California ${ }^{104}$ where the Court upheld a compelled blood test of an individual suspected of drunk driving. Winston in fact began with a quote from Schmerber: "That we today hold that the Constitution does not forbid the States['] minor intrusions into an individual's body under stringently limited circumstances in no way indicates that it permits more substantial intrusions, or intru-

88387 US 523, 530-31 (1967).

99 801 F2d 893, 900-01 (7th Cir 1986).

$100240 \mathrm{Ga} 866,242$ SE2d 713, 715 (1978).

101470 US 753 (1985). See generally Annotation, Admissibility, in Criminal Case, of Physical Evidence Obtained without Consent by Surgical Removal from Person's Body, 41 ALR4th 60 (1985).

102470 US at 759.

103 Id at 766.

104384 US 757 (1966). 
sions under other conditions." 105 The blood tests in Schmerber involved only minimal intrusion. ${ }^{108}$ Winston concluded that "Schmerber recognized society's judgment that blood tests do not constitute an unduly extensive imposition on an individual's personal privacy and bodily integrity."107

Using the Schmerber framework as developed in Winston, the courts should classify compulsory vaginal and rectal examinations as "extensive" intrusions and apply the compelling need standard. ${ }^{108}$ Admittedly, several lower federal courts have upheld intrusive body cavity searches in the special context of border and prison searches, ${ }^{109}$ where a less stringent standard of antecedent justification than probable cause generally is required to search for contraband, such as illegal drugs, hidden in the defendant's vagina $^{120}$ or rectum. ${ }^{111}$ Yet both border and prison searches are properly viewed as a unique and narrow exception to the Fourth Amendment's stricture, and courts and commentators have long seen them as such. ${ }^{112}$ Winston applies elsewhere, and its holding leaves no doubt that only the most demanding antecedent justification-a finding of compelling need-can validate coerced vaginal or rectal examinations of defendants by government-appointed physicians. Winston also makes clear that such examinations do not satisfy the compelling need standard even when they are likely

108 Winston, 470 US at 755, quoting Schmerber, 384 US at 772.

${ }^{108}$ Schmerber, 384 US at 771.

${ }^{107}$ Winston, 470 US at 762. In its most recent decision involving physical examinations, the Court upheld a routine administrative drug testing program. In Skinner $v$ Railway Labor Exec. Ass'n, several railroad labor groups challenged a plan by the Federal Railroad Administration to impose routine blood, breath, and urine tests on industry employees. 109 S Ct 1402 (1989). Relying on Schmerber, the Court upheld the random drug-testing program, stressing that the tests were only minimally intrusive. Id at 1417-18.

${ }^{108}$ Winston, 470 US at 762.

100 See Annotation, Body Search-Force or Threat of, 66 ALR Fed 119, 144-59 (1984) (listing cases).

${ }^{110}$ See, for example, United States v Shields, 453 F2d 1235, 1236 (9th Cir 1972) (removal of condom containing heroin from defendant's vagina during border search did not violate Fourth Amendment because officers had "clear indication" that contraband was present prior to search).

${ }^{111}$ See, for example, United States v York, 578 F2d 1036, 1041 (5th Cir 1978) (prison officials need merely show reasonableness, not probable cause, to search inmate's rectum for partially protruding balloon containing marijuana).

122 See, for example, United States v Martinez-Fuerte, 428 US 543, 551, 567 (1976) (need to police nation's borders and control immigration); York, $578 \mathrm{~F} 2 \mathrm{~d}$ at 1041 (exigencies of prison environment and inmates' diminished expectation of privacy); and 66 ALR Fed at 124 ("both prison searches and border searches present unique situations"). 
to reveal criminal evidence. ${ }^{113}$ Surely complainants are entitled to equal, if not greater, Fourth Amendment protection.

B. California's Fourth Amendment Approach to Compulsory Physical Examinations

California courts have applied the Fourth Amendment to compulsory physical examinations of both defendants and complainants in sex offense prosecutions. These decisions offer a practical guide for other courts to evaluate defendants' requests that complainants be physically examined by defense or court-appointed experts.

In People $v$ Scott, the trial court ordered a physician to perform a medical technique that would make an accused sex offender ejaculate involuntarily, so that the government could use the semen for medical tests. The technique involved massaging the prostate gland through the rectum. The prosecution hoped to gain evidence showing that the defendant suffered from the same sexually transmitted disease as his daughter, whom he was accused of molesting. ${ }^{114}$ The California Supreme Court held that the examination proposed in Scott violated the Fourth Amendment. ${ }^{115}$ The court employed a balancing test consistent with U.S. Supreme Court decisions. ${ }^{116}$ First, said $S c o t t$, the court must engage in a balancing test "to determine whether the character of the requested search is appropriate." Second, the court must be convinced that there is a compelling need for the evidence likely to be obtained.117

The Scott court then established guidelines to determine whether the proposed physical examination was reasonable:

Factors which must be considered include the reliability of the method to be employed, the seriousness of the underlying criminal offense and society's consequent interest in obtaining a conviction, the strength of law enforcement suspicions that evidence of crime will be revealed, the importance of the evi-

113470 US at 759; see note 102.

134 Cal 3d 284, 578 P2d 123, 125 (1978).

115 Id at 128.

110 Id at 127. The court in Scott tailored its Fourth Amendment analysis to conform with the Court's jurisprudence. For example, it referred to Camara, 387 US at 536-37, for the view that the Fourth Amendment requires a balancing of "the need to search against the invasion which the search entails." Scott also attempted to satisfy Schmerber and other Supreme Court decisions by noting that "the circumstances which permit penetrations beyond the body's surface are particularly limited, since such intrusions may readily offend those principles of dignity and privacy which are protected by the Fourth Amendment."

117 Id. 
dence sought, and the possibility that the evidence may be recovered by alternative means less violative of Fourth Amendment freedoms. These considerations must, in turn, be balanced against the severity of the proposed intrusion. Thus, the more intense, unusual, prolonged, uncomfortable, unsafe or undignified the procedure contemplated, or the more it intrudes upon the essential standards of privacy, the greater must be the showing for the procedure's necessity. ${ }^{118}$

Scott held that the proposed examination would violate the Fourth Amendment for two reasons. First, the technique involved "the most intimate of bodily functions, traditionally and universally regarded as private ...." Second, the evidence desired, "though possibly 'relevant' in the broadest sense of the term," was of limited probative value. ${ }^{119}$

These considerations apply with equal force to compulsory vaginal and rectal examinations of complainants. That a court-ordered vaginal or anal examination "intrudes upon essential standards of privacy" is obvious. As the California Court of Appeal subsequently noted in People $v$ Nokes, "any genital or rectal examination has a vastly higher privacy quotient than examination of the eyes, the hair, the throat or the extremities."120 Nokes was concerned with a proposed rectal examination of the defendants' son, whom defendants had allegedly sodomized. In denying the defendants' request, the Court of Appeal reasoned that even though the proposed examination was "simple" and would be carried out by the defendants' expert physician "with all possible regard for the son's well-being, an examination encompassing the insertion of a finger into the son's rectum could not be characterized as simple and nontraumatic for him. Given the nature of the son's testimony, the subject of the examination in this case would be a nine-yearold boy who had already been molested on repeated occasions by the insertion of a finger into his anus." "121

As for the second consideration in Scott-the relevancy of the evidence likely to be obtained by the physical examination-the court acknowledged that the proposed intrusion might have yielded circumstantial evidence showing that the defendant suffered from the same disease as the complainant. However, Scott stressed that such evidence in and of itself could not have proved

\footnotetext{
118 Id (citations omitted).

110 Id at 128.

120183 Cal App 3d 468, 479, 228 Cal Rptr 119 (1986).

121 Id.
} 
that the defendant had infected her. ${ }^{122}$ A similar point might also be made with respect to rectal and vaginal examinations of complainants. Evidence of penetration can be relevant, especially when the alleged victim is a young child. But rarely can such evidence positively identify a particular defendant. And even when penetration is a material element of the offense, it may be possible for the prosecution to prove penetration beyond a reasonable doubt without any physical evidence.

In sum, the Scott balancing test casts doubt on the accused sex offender's ability to obtain a compulsory rectal or vaginal examination given the powerful Fourth Amendment interests at stake. It therefore limits constitutionally unwarranted criminal discovery that infringes on victims' rights.

\section{ConcLusion}

Defendants charged with sex offenses are increasingly demanding that their own medical experts, or independent experts appointed by the trial court, conduct physical examinations of complainants. They claim that due process entitles them to such exams. Most state courts that have considered the issue have avoided the constitutional inquiry and framed their decisions solely in terms of whether the trial court abused its inherent discretionary power by ordering a physical examination against the complainant's wishes. But a handful of decisions do conclude that defendants have a due process right to compel such exams. This minority view contravenes the pertinent Supreme Court jurisprudence, which carefully limits the scope of criminal discovery.

By applying the Fourth Amendment to compulsory physical examinations, courts can provide a modicum of protection to the alleged victims of crime. The Fourth Amendment approach shifts trial judges' focus away from absolute discovery rights for defendants and toward a proper recognition of the uniquely intrusive nature of physical examinations of complainants-mostly young children-who may have been victimized by crimes of extreme depravity. Forcing complainants to submit to intrusive physical inspections as a prerequisite for enforcing laws designed to protect children hinders the enforcement of those laws. ${ }^{123}$ And it punishes

122 Scott, $578 \mathrm{P} 2 \mathrm{~d}$ at 128.

${ }^{123}$ As in the context of compulsory psychiatric examinations, a prosecution may not be contingent on any physical examination. Yet requiring a vaginal or rectal examination on behalf of the defendant may prevent a prosecution dependent on the witness testimony of the victim, who might refuse to testify if coerced into an intrusive examination. 
crime victims who seek to vindicate themselves and society through the justice system. Complainants should not face this Hobson's Choice, especially when the sacrifice is unnecessary. Defendants' due process rights are already protected; prosecutors must disclose to them any exculpatory evidence that a consensual examination might reveal. The Fourth Amendment approach to compulsory physical examinations would restore the proper limits of defense discovery while recognizing that crime victims also have constitutional rights. 
